\title{
Research on Collation between English Learning Anxiety Degree of Level B Students and Oral Performance
}

\author{
Yongyan SONG
}

\author{
School of Foreign Languages, Jilin Agricultural University, Changchun 130118, China \\ Email: 1012932249@qq.com
}

Keywords: Collation; total; level B; each dimension; anxiety degree; oral performance

\begin{abstract}
The purpose of this research is to provide a basis for improving foreign language oral teaching methods. The research method is questionnaire. The data of the investigation and oral performances are analyzed by using SPSS software package to solve the problems: (1) How are the anxiety degrees of each dimension and total anxiety? (2) What is the collation between oral performance and the anxiety degrees of each dimension and the total anxiety degree? (3) What is the collation between the anxiety degrees of each dimension? The research results are the total anxiety degree is very high and communication apprehension and oral anxiety are relatively high; the oral performance of level B students has no significant collation with anxiety degrees of each dimension and total anxiety degree. However, the collation between the anxiety degrees of each dimension is very significant. The original is that the collation between oral anxiety and communication apprehension is the largest.
\end{abstract}

\section{Introduction}

Researches on foreign language learning anxiety flourished in the 1970s. Domestic and foreign experts and scholars have done a lot of researches on the collation between anxiety and listening, speaking, reading and writing. The author reviews the research results that domestic and foreign scholars have obtained about the collation between learning anxiety and oral English. The research results of Gardner, Smythe, Clement \& Gliksman (1976) [1] and Naiman, Frohlich, Stern \& Todesco (1978) [2] showed that there was negative collation between foreign language learning anxiety and oral performance. Young (1991) [3] found that foreign language learning anxiety and oral performance was irrelevant. Chen Jie (1997) [4] found that there was negative collation between foreign language learning anxiety and oral performance. The empirical results of Zhang Yuanrong (2002) [5] showed in oral English class, non-English major postgraduates felt less anxious than beginners. Li Binbin (2005) [6] found that in the language classroom, hindering anxiety had a huge negative impact on the spoken language. Cheng Yanping (2007) [7] found that there was a negative collation between students' classroom anxiety and oral expression. Faced with different research results, it is necessary to do further research on foreign language learning anxiety and oral performance. Li Hui \& Jiang Yadan (2014) [8] have done the research on oral class anxiety of level A students. This research is on the anxiety degrees of each dimension, total anxiety degree of level B students, the collation between foreign language learning anxiety and oral performance of level B students and the collation between the anxiety degrees of each dimension.

\section{Research design}

\subsection{Research problems}

This research mainly focuses on the following problems: (1) How are the anxiety degrees of each dimension and total anxiety degree of level B students? (2) What is the collation between oral performances of level B students and the anxiety degrees of each dimension and the total anxiety degree? (3) What is the collation between the anxiety degrees of each dimension?

\subsection{Research subjects}

All the freshmen in Jilin Agricultural University take the grading test after the enrollment. According to test scores and college entrance examination English scores, they are divided into 
three levels: level A, B and C. The subjects of the research are 98 undergraduates from level B in grade 2014. The specific information of the subjects is shown in table 1 . See table 1.

Table 1 Specific information of the subjects

\begin{tabular}{ccccccc}
\hline Item & \multicolumn{2}{c}{ sex } & \multicolumn{2}{c}{ source } & \multicolumn{2}{c}{ subject } \\
\hline & male & female & city & country & art & engineering \\
$\mathrm{N}$ & 52 & 46 & 48 & 50 & 51 & 47 \\
Proportion (\%) & 53.06 & 46.94 & 48.98 & 51.02 & 52.04 & 47.96 \\
\hline
\end{tabular}

\subsection{Research tools}

\subsubsection{Questionnaire}

Questionnaire are made mainly based on Horwitz's (1986) [9] Foreign Language Classroom Anxiety Scale (FLCAS) and combined with domestic researchers' classification criteria of foreign language learning anxiety from Chen Xiaoqin (2008)[10] and Zhang Limin (2009)[11]. The 33 questions in the questionnaire are divided into 5 dimensions: oral anxiety, test anxiety, communication apprehension, fear of negative evaluation and classroom environment anxiety.

2.3.2 Oral test and grading criteria

There are two types of questions in the oral test designed by the three teachers from the research team, including reading aloud and answering questions. Each type of questions includes two questions, the topics of which are related to the students' campus life. The total mark of the test is 20 points. In order to ensure the oral performances are fair and reasonable, we adopt English oral test grading criteria [12].

\subsection{Research process}

109 level B undergraduates from Jilin Agricultural University in grade 2014 were investigated by using the questionnaire. Among 109 questionnaires, 98 were collected and effective rate is 89.91\%. The subjects took the oral test on the computer, and the three teachers from the research team graded the students' oral recording. Each recording was graded by three teachers and the average score is the student's oral performance. Then, SPSS software package is used to analyze the results of the investigation and oral performances to obtain the total anxiety degree, anxiety degrees of each dimension, the correlation between oral performance and the English learning anxiety degree and the collation between the anxiety degrees of each dimension.

\section{Result analysis and discussion}

The data of the investigation into the anxiety degrees of each dimension and total anxiety degree are analyzed. The results are shown in table 2. See table 2.

Table 2 Descriptive statistics of the anxiety degrees of each dimension and total anxiety degree

\begin{tabular}{cccccc} 
Item & N & Min & Max & M & SD \\
\hline oral anxiety & 98 & 1.33 & 4.22 & 2.9048 & .61565 \\
test anxiety & 98 & 1.40 & 4.60 & 2.8388 & .64194 \\
communication apprehension & 98 & 1.40 & 4.40 & 2.9551 & .59864 \\
a fear of negative evaluation & 98 & 1.60 & 4.80 & 2.8061 & .63794 \\
classroom environment anxiety & 98 & 1.78 & 4.33 & 2.8889 & .46461 \\
total & 98 & 55.00 & 134.00 & 95.5408 & 15.13252 \\
Valid N (listwise) & 98 & & & & \\
\hline
\end{tabular}

According to table 2, we can see the anxiety degrees of different dimension are different. The average score of communication apprehension is 2.9551, the highest. The second is oral anxiety 2.9048. Therefore, level B students who communicate with English have higher anxiety degree. The reason is that the English standard of level B students is lower and they are the students of "after 90s", with low ability to communicate with others because they focused too much on the academic achievements in high school, which affected their communicative ability. However, the average 
score of a fear of negative evaluation is the lowest, which is related with the characteristics of "after 90s", they are rich in knowledge and more confident than the previous generations [13]. The average of the total anxiety is 95.5408, which is higher than the research results of Zhang Huixiao (2012) [14] and Gao Yuan (2011)[15]: 91.3 and 91.586. Therefore, we reached the conclusion that the students with lower level have higher anxiety degree.

Anxiety degree can be divided into four levels according to the scores that the subjects got. They are no anxiety, low anxiety, moderate anxiety and high anxiety. The students whose scores are below 66 have no anxiety; those whose scores are between 66 and 99 have low anxiety; those whose scores are between 100 and 132 have moderate anxiety, and those whose scores are above 132 have high anxiety. See table 3.

Table 3 Different anxiety degrees

\begin{tabular}{cccccc}
\hline & Item & Frequency & Percent & Valid Percent & Cumulative Percent \\
\hline \multirow{4}{*}{ Valid } & no anxiety & 2 & 2.0 & 2.0 & 2.0 \\
& low anxiety & 32 & 32.7 & 32.7 & 34.7 \\
& moderate anxiety & 62 & 63.3 & 63.3 & 98.0 \\
& high anxiety & 2 & 2.0 & 2.0 & 100.0 \\
& total & 98 & 100.0 & 100.0 & \\
\hline
\end{tabular}

According to table 3, the percentage of no anxiety and high anxiety are the same, and both of them are low. However, the percentage of moderate anxiety is 63.3\%, which indicates the anxiety degree of the subjects is relatively high. The reason is that the English standard of the students with level B is lower, they are lack of motivation and interest in foreign language learning, and they don't have proper learning methods. Therefore, their foreign language learning anxiety is relatively high.

The collation between anxiety degrees of each dimension is analyzed, and the result is shown in table 4 . See table 4

Table 4 Collation between anxiety degrees of each dimension

\begin{tabular}{lcccccc}
\hline \multicolumn{1}{c}{ Item } & & $\begin{array}{c}\text { oral } \\
\text { anxiety }\end{array}$ & $\begin{array}{c}\text { test } \\
\text { anxiety }\end{array}$ & $\begin{array}{c}\text { communi } \\
\text { cation } \\
\text { apprehe } \\
\text { sion }\end{array}$ & $\begin{array}{c}\text { a fear of } \\
\text { negative } \\
\text { evaluation }\end{array}$ & $\begin{array}{c}\text { classroom } \\
\text { environment } \\
\text { anxiety }\end{array}$ \\
\hline oral anxiety & $\mathrm{r}$ & 1 & $.535^{* *}$ & $.730^{* *}$ & $.550^{* *}$ & $.464^{* *}$ \\
& $\mathrm{p}$ & & .000 & .000 & .000 & .000 \\
test anxiety & $\mathrm{n}$ & 98 & 98 & 98 & 98 & 98 \\
& $\mathrm{r}$ & $.535^{* *}$ & 1 & $.426^{* *}$ & $.563^{* *}$ & $.379^{* *}$ \\
communication & $\mathrm{p}$ & .000 & & .000 & .000 & .000 \\
apprehension & $\mathrm{n}$ & 98 & 98 & 98 & 98 & 98 \\
& $\mathrm{r}$ & $.730^{* *}$ & $.426^{* *}$ & 1 & $.534^{* *}$ & $.504^{* *}$ \\
a fear of negative & $\mathrm{p}$ & .000 & .000 & & .000 & .000 \\
evaluation & $\mathrm{n}$ & 98 & 98 & 98 & 98 & 98 \\
Classroom & $\mathrm{r}$ & $.550^{* *}$ & $.563^{* *}$ & $.534^{* *}$ & 1 & $.390^{* *}$ \\
environment & $\mathrm{p}$ & .000 & .000 & .000 & & .000 \\
anxiety & $\mathrm{n}$ & 98 & 98 & 98 & 98 & 98 \\
\hline
\end{tabular}

From table 4, we can see oral anxiety and test anxiety, communication apprehension, a fear of negative evaluation and classroom environment have very significant collation $(r=0.535 ; r=0.730$; $r=0.550 ; r=0.464$, ps $<0.000$ ); test anxiety and communication apprehension, a fear of negative evaluation and classroom environment have very significant collation ( $r=0.426 ; r=0.563 ; r=0.379$, ps $<0.000$ ); communication apprehension and a fear of negative evaluation and classroom 
environment have very significant collation ( $\mathrm{r}=0.534$; $\mathrm{r}=0.504$, $\mathrm{ps}<0.000$ ); a fear of negative evaluation and classroom environment have very significant collation $(\mathrm{r}=0.390, \mathrm{p}<0.000)$. The result shows that each dimension anxiety is very significantly related to each other and the collation between oral anxiety and communication apprehension is the largest.

The correlation between oral performance and the English learning anxiety degree is analyzed, and the result is shown in table 5 . See table 5.

Table 5 Correlation of the anxiety degrees of each dimension and total anxiety degree and oral performance

\begin{tabular}{lccccccc}
\hline Item & & $\begin{array}{c}\text { oral } \\
\text { anxiety }\end{array}$ & $\begin{array}{c}\text { test } \\
\text { anxiety }\end{array}$ & $\begin{array}{c}\text { communication } \\
\text { apprehension }\end{array}$ & $\begin{array}{c}\text { a fear of } \\
\text { negative } \\
\text { evaluation }\end{array}$ & $\begin{array}{c}\text { classroom } \\
\text { environment } \\
\text { anxiety }\end{array}$ & total \\
\hline \multirow{3}{*}{ oral } & $r$ & $085-$. & -.016 & -.003 & .018 & -.101 & -.076 \\
performance & $p$ & .403 & .877 & .973 & .857 & .321 & .457 \\
\hline
\end{tabular}

According to table 5, we can see the oral performance of the level B students has no significant collation with the total anxiety degree $(\mathrm{r}=-0.076, \mathrm{p}=0.457>0.05)$; oral performance has no significant collation with oral anxiety, test anxiety, communication apprehension, a fear of negative evaluation and classroom environment anxiety $(r=-0.016, p=0.877>0.05 ; r=-0.003, p=0.973>0.05$; $\mathrm{r}=0.018, \mathrm{p}=0.857>0.05 ; \mathrm{r}=-0.101, \mathrm{p}=0.321>0.05)$. This research result is consistent with that of Young $(1991)^{[3]}$.

\section{Conclusion}

On the basis of the research, we can conclude that the collation of the oral performance of level $\mathrm{B}$ students and the anxiety degrees of each dimension and total anxiety degree is not significant. However, the average of total anxiety is 95.5408, which indicates the anxiety degree of level B students is very high, especially in communication apprehension and oral anxiety. Therefore, as English teachers we should improve oral teaching methods to stimulate students' interests, create a relaxed atmosphere for learning to reduce students' anxiety degree and find the students' bright spots to avoid harming their self-esteem, which will help increase teaching quality.

\section{Acknowledgment}

This paper is supported by Jilin Provincial social science funds (2014 WY18)

\section{References}

[1]. Gardner, R. P. Smythe, R. Clement, \& L. Gliksman. Second-language learning: a social-psychological perspective [J]. Canadian Modern Language Review, 1976 (32):198-213.

[2]. Naiman, N., M. Frohlich, D. Stern, \& A. Todesco. The Good Language Learner. Toronto Ontario Institute for Studies in Education, 1978.

[3]. Young, D. Creating a lower anxiety classroom environment: What does language anxiety research suggest? [J]. Modern Language Journal 1991, 75: 426-438.

[4]. Chen Jie The Relationship between Classroom Anxiety of English Learning Students and the Level of Oral English[J]. Foreign Language Teaching Abroad, 1997 (1): 15-18. (In Chinese)

[5]. Zhang Yuanrong. A Study of Classroom Spoken English Activities and Stress of Non-English-majors [J]. Shandong Foreign Languages Journal, 2002 (5): 67-70. (In Chinese)

[6]. Li Binbin. The Influence of Language Anxiety on Oral English Learning [J]. Journal of Taizhou University, 2005 (1): 68 -71. (In Chinese) 
[7]. Cheng Yanping, He Qiguang \& Han Xiaoli. The Effect of English Classroom Anxiety on College Students' Oral Performance[J]. Language Teaching and Linguistic Studies, 2007 (1):89-95. (In Chinese)

[8]. Li Hui \& Jiang Yazhou. Empirical research on oral English Classroom Anxiety of College English Level A students[J]. Journal of Guiyang College of Traditional Chinese Medicine, 2014 (7): 62-64. (In Chinese)

[9]. Horwitz E. M.. Horwitz \& J. Cope. Foreign language classroom anxiety [J]. Modern Language Journal, 1986 (70):125-132.

[10]. Chen Xiaoqin. Study on the Collation between Foreign Language Anxiety and Students' Achievement in English Learning-An investigation into the non-English majors in Guilin University of Technology[J]. Journal of Guilin Normal College, 2008 (9):99-102. (In Chinese)

[11]. Zhang Limin, Yin Demo \& Du Panpan. Enlightenment of oral English Teaching on Foreign Language Learning Anxiety - An investigation into English major students of Xihua University[J]. Science \& Technology Information, 2009 (28): 547-548. (In Chinese)

[12]. Oral English Test Grading Criteria [EB/OL]. http://wenku.baidu.com/view/848846ef6294dd88d0d26b65.html. 201112 27/2016 0724 (In Chinese)

[13]. Xiong xin \& Chen Xiao yue. Psychological Characteristics Analysis of "after the 90s" College Students and Countermeasures [J]. Intelligence, 2014 (27):122. (In Chinese)

[14]. Zhang Huixiao \& Guo Hui. A Study on Foreign Language Learning Anxiety in Computer and Network Environment and Relevant Countermeasures [J]. Journal of Hebei University of Science and Technology (Social Sciences), 2012 (1) :107-111. (In Chinese)

[15]. Gao Yuan. A Study on the Correlation between the English Language Anxiety of College Students and the Use of Language Learning Strategies .Xian: SHAANXI NORMAL UNIVERSITY. 2011. (In Chinese) 